\title{
ENTREPRENEURSHIP, ORGANIZATION AND ECONOMIC PERFORMANCE AMONG SPANISH FIRMS, 1930-1975. THE CASE OF THE MOTOR INDUSTRY ${ }^{1}$.
}

\author{
Albert Carreras (Universitat Pompeu Fabra, Barcelona) \\ Salvador Estapé-Triay (Universitat Pompeu Fabra, Barcelona)
}

1 The paper has been prepared with the support of the Spanish DIGES grant PB96-0301. 


\section{abstract}

Before the Civil War (1936-1939), Spain had seen the emergence of firms of complex organizational forms. However, the conflict and the postwar years changed this pattern. The argument put forward in this paper is based on historical experience, the efforts will be addressed to explain the development of Spanish entrepreneurship during the second half of the twentieth century. To illustrate the change in entrepreneurship and organizational patterns among the Spanish firms during the Francoist regime we will turn to the case of the motor vehicle industry.

JEL: L62, M13, N64

Keywords: entrepreneurship, motor industry, multinational entreprises, organizational capabilities, state intervention. 


\section{Introduction}

As it corresponds to a slow growing and slow modernizing country, Spanish firms were, by 1930, a mix of national and foreign entrepreneurship with fairly complex organizational structures. This paper will address two related sets of issues: a) the change in entrepreneurship patterns among Spanish firms during the four decades of the Franco régime (1936-1975), and b) the change in organizational patterns. We suggest that both issues are related.

We organize the paper as follows. A short summary of the main entrepreneurship and organizational features of Spanish business world around 1930 is the content of the section 1. The civil war and the second world war developments form the second section. The third is devoted to the clash between state and private entrepreneurship during the autarkic period (1945-1954), as shown with the case study of the motor industry. After a short mention to similar experiences in other developing countries (Egypt and Brazil) we expand the argument to the years 1955-1973, when Spain increasingly accepted foreign investment and entrepreneurship. In the sixth section we come back to the organizational developments during the Franco period, focusing on the limitations suffered by business organization because of shifting entrepreneurship patterns.

\section{Entrepreneurship, emergence of organizational complexity and accumulation of organizational capabilities before the Civil War.}

Any consideration of entrepreneurial and organizational issues in the pre-1936 Spain has to begin by the awareness of the size and sectoral specialization of big firms at that moment. We know the 1930 ranking of big firms (all sectors), classified by assets (see Table 1).

Table 1. The twenty top Spanish firms in 1930, classified by theirs assets.

\author{
1. MZA \\ 2. Norte \\ 3. $\mathrm{CHADE}$ \\ 4. Barcelona Traction, Light \& Power \\ 5. Banco de España \\ 6. Riegos y Fuerzas del Ebro \\ 7. R.C.Asturiana \\ 8. S.M.M.Peñarroya \\ 9. C.Telefónica \\ 10. FFF.CC.Tánger-Fez \\ 11. Andaluces \\ 12. S.E.Construcción Naval \\ 13. Catalana de Gas \\ 14. Rio Tinto \\ 15. C.A.Tabacos \\ 16. C.Transatlántica \\ 17. CAMPSA \\ 18. Oeste \\ 19. S.G.Azucarera \\ 20. Banco de Bilbao
}

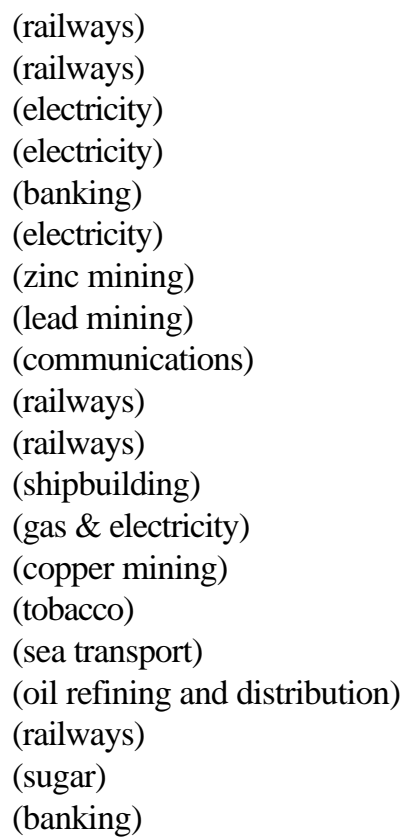


This is the map of top business. There are railway companies -including the two largest. There are public utilities of various kinds, but mainly electrical. There are also mining companies. Among the rest it is worth mentioning the two banks (the central bank and the largest private commercial bank), and three firms mainly involved in manufacturing (shipbuilding, tobacco, oil and sugar). The mining companies were also involved in manufacturing activities, just as the oil company -more oriented towards distribution than to manufacturing. Half of them originated from or went through a major merger, facing the challenges of substantive internal reorganization. The ownership was private (with some public involvement in Oeste -formerly a private firm that went bankrupt but that was supported with public funds because of regional policy- and in CAMPSA -the private company that managed the oil refining and distribution monopoly establisehd in 1927 after the nationalization of the assets of all the private firms working in the oil business in Spain). Foreign capital was predominant in seven, and a strong minority in five. As the size of the firms was large enough, the ownership happened to be fragmented and the quotation in the stock exchange was more the rule than the exception.

As far as the literature allows us to go, all these firms were large and complex enough to require a lot of investment in organizational capabilities. They had a long tradition of top management. They were multi-plant or they had large networks. The need for differentiated functional offices was not only felt, but fully deployed. Just as many other smaller firms, they were offering a real career within the firm for their mid-level managers. We lack the proper kind of research on this particular point, but all the evidence suggests that lawyers and engineers were regularly hired and were offered good professional prospects. The industrial relations were complicated enough to receive detailed attention by specialized managers. In quite a few cases (mainly in the railway companies and in the public utilities) a pack of welfare services was designed for the employees. The railway companies were also pioneering the adoption of computers for their internal management. Taylorism was known and used in some manufacturing firms, mainly in those fields more congenial with Taylor's approach: steel works [Vegara, 1971].

On the contrary, there is no hint at all of the adoption of the divisionalized structure. The firms involved in more than one major business field were of three kinds: a) mining companies, involved in more than one product and usually both mining and manufacturing; $b$ ) public utilities, involved in production and distribution; and c) Catalana de Gas, with interests in gas and electricity. Lower in the ranking there were companies like the chemicals (U.E.Explosivos and Cros,S.A.) entering in various related lines of business. All in all, the organizational complexity was more an outcome of the scale of the companies than of their scope.

The predominance of service companies among the largest also meant an internal market bias. Only the mining companies were clearly oriented towards the export markets. Indeed, their foreign ownership was closely related with the knowledge of world markets and marketing. The manufacturing firms were more oriented towards the Spanish market. SECN was the Spanish counterpart of Vickers, associated with Spanish banks and with Spanish former shipbuiilders. C.A.Tabacos and CAMPSA were private firms exploiting a fiscal monopoly. Only S.G.Azucarera could have had some export orientation, but it was negligible.

The strength of the top Spanish firms by 1930 -just as by 1936- was their size and their efficient internal organization. Some of them underwent major labor unrest in the 1910s, and they learned in the following decade how to avoid internal social turmoil. All the firms, even those managing fiscal monopolies, were fully aware of the risks of loosing competitiveness. 


\section{A period of conflicts (1936-45)}

The situation aforementioned changed dramatically after the Civil War. The Civil War "per se" (1936-1939) was extremely damaging for firms organizational structures. Most of the big firms happened to have their assets and their managers in both sides of the war. More often than not, their headquarters were in the Republican side (Madrid, Barcelona, Bilbao) while their owners were fully supportive of the Francoists. Furthermore, a wave of collectivizations in the more leftist oriented Republican regions challenged the traditional organizational schemes of private firms. The outcome was a lot of confusion, a dissolving or an upsetting of the usual hierarchies and the internalization of civil conflict. Moreover, many middle and top managers were killed or they had to avoid this fate by running away (this is not to forget that also many workers were killed -we are simply concentrating on the effects of the war on the management).

Once the war was over it was difficult to come back to the past equilibrium. So many people killed, the defeat of one side and the success of the other, the hate between workers and owners and managers, the dissolution of the trade unions, the sudden reduction in real wages, the creation of a fascist corporatist movement (the "vertical trade union") -everything was completely different from the liberal world of the pre-war years. A committee was created to organize the return of the collectivized firms back to their owners -but the new context was not the one dreamed by the defenders of a liberal order.

A fascist, pro-autarky, approach was dominating among the new ruling class. The capitalists that were not fully supportive of the Francoist movement did not have an easy time. As the market was extensively interfered by new laws and decrees, the political favor became far more important than economic efficiency and market competitiveness. The foreign-owned enterprises were seen as politically incorrect -the fascists were extremely nationalists- and had to support a lot of pressure to sell their firms or to accept new Spanish majorities among their shareholders. A movement of ownership transfers from foreign hands to Spanish (public or private) ones, was set in motion. There was an actively developing group of public companies in the industry and the tertiary and nationalising "strategic" sectors [Carreras and Tafunell 1993, 1997]. However, the interventionist system performed very poorly. In 1944 Telefónica (an ITT firm) could not renew its licence and was compensated with 50 milion gold pesetas, cash. Out of it, the Spanish State created in 1945 the new "Compañía Telefónica Nacional de España"[Little 1985]. Hispano-Suiza underwent the same fate. The railway companies (that had a lot of foreign capital) were nationalized between 1942 and 1944. Vickers had to withdraw from SECN. The foreigners (mainly Belgians) were kicked off from "Barcelona Traction" and "Riegos" (the biggest electricity producers), and a close friend of Franco managed to become the new owner of the firm. As late as 1954 Riotinto was forced to sell to a consortium of Spanish banks [GómezMendoza, 1994]. The same year Ford abandoned Spain after 35 years of industrial activity [Estapé-Triay, 1997a, 1997b].

In each of these cases, the shock of the war was coupled to the shock of a radical change in ownership and in the general context of the firm. Managers had a bad time and, what is much worse, the internal organization schemes and culture were partially or wholly distroyed. Only the firms that in the pre-war years were completely Spanish owned, could continue without major changes. It was the case of most of the commercial banks and of some of the public utilities. The changes were the most extreme when a nationalization was made: Telefónica, RENFE, Hispano-Suiza, were cases in point. There the switch was from (partial or total) foreign and private ownership to totally Spanish and public. The top and middle 
management was very much altered, and so did the organizational culture. The new managers were, typically, military. In some cases they had an engineer training, but this was not always the case. The engineers had also their chance, mainly when they were ideologically close to the new Régime. Both, military and engineers, coincided in a nationalistic and technical approach that was hostile to the market, to the price system and to economic efficiency and that supported organizational discipline, the superiority of the State national interest over the market (expressed in administered prices), and technical feasibility. They were actively in favor of autarkic policies.

Juan Antonio Suanzes was the most distinguished character among this new class of top managers [Ballesteros, 1993]. He was a naval engineer working at SECN (Vickers) before the war. As a highly qualified technical staff, he became very much resented against Vickers. He thought that their investment decisions were governed by capitalistic interests that were inimical to the Spanish ones. So, some orders that could have been developed at SECN were passed by Vickers to other firms in the group, outside Spain. Suanzes hated Vickers because of this and because the feeling of forced inferiority of Spanish managers as compared with foreign ones -more congenial with the long term interests of the ownership. He was close friend of Franco and after the civil war he was nominated Chairman of the newly created INI (the Spanish IRI, the Industrial National Agency). He commanded the INI since its creation in 1941 to 1963 [Schwartz and González 1978; Comín and Aceña 1991]. During six years, from 1945 to 1951, he also was Minister of Industry, and achieved its maximum political influence. He created many new firms -all of them named "Empresa Nacional" (National Enterprise)- in a wide range of manufacturing sectors. From the Ministry and from the INI command board, he pushed away from Spain as many foreign capitalists as he could. He promoted the military and the engineers to top management responsabilities. He defined internal organization structures that were military oriented and with a typical bureaucratic form. As his goals were never of an economic nature but of a political, military or national nature, his system of rewards was more based in political loyalty and, secondly, technical achievement than in any kind of economic efficiency.

Therefore things were not the same after the civil war. The almost immediate outbreak of the international conflict and the political and economical options of the new regime changed the governing co-ordinates of the country. The political system which emerged after the Civil War (1936-39) sought to make Spain industrially self-sufficient, especially in the so-called "strategic sectors" and those related with defence. Moreover, in a situation of scarce resources, during and after the civil war, the promotion of stateowned enterprise was made to the detriment of private enterprise [Carreras and Tafunell 1997]. In many cases, the prejudice of the state leaders against private ownership went beyond any economic rationality. It can be stated that Spanish business of the forties and early fifties, maintained and promulgated by the official authorities, was full of patriotism. It will be argued that these decades are decisive to understand most of the country's backwardness. ${ }^{2}$ Indeed, the decisions adopted during the period of the World War II had consequences in the long run. The economic growth guidelines promoted by the first Franco regime period from the end of the civil war meant a breaking point with

\footnotetext{
${ }^{2}$ Catalan has studied the impact of the Second World War in the Spanish economy from a comparative perspective. He points out, after examining the costs and benefits of the external conflict and the position of the European neutral economies, that the Second World War, even more than the First World War, implied a frustrated episode for the Spanish economic development. Indeed, the Francoist regime, on the one hand, boosted an economic and social policy inspired by those adopted in Nazi Germany and Fascist Italy from the mid-thirties and, on the other hand, they adopted a foreign policy favourable to both countries during the first years of World War II. Catalan (1995).
} 
the development path of the two previous regimes, i.e. the Restoration and the Republic. Not only did it lose the ground gained with respect the industrialised countries during the first three decades of the century, but even more importantly it changed the structural basis of the Spanish economy which has subsequently conditioned her economy until recently. This structural modification came through a complete break with the parameters of successful business. Accordingly, the roots of contemporary Spanish backwardness have to be found, above all, in the origins of the Francoist regime and the decisions adopted freely by the Spanish authorities of the moment [Catalán 1995].

The implementation of strongly nationalistic economic policies and the eruption of new forms of business style were determinant for the performance of the already established foreign concerns. In the Spanish case, autarky and intervention are two phenomena which cannot be separated when discussing the Spanish post-civil war economy. The intervention was originally justified because of the necessities of the civil war. However, it continued even after the war, with the Francoist regime claiming intervention was necessary to protect the Spanish economy from the effects of the Second World War. Despite this claim, the economic authorities of the regime, far from eliminating the existing controls at the end of the Second World War, kept them with more or less the same intensity for at least fifteen years [Gómez Mendoza 1994].

Furthermore, the role of the government was one of the most influential factors in the poor performance of the Spanish business economy. After the civil war the State became responsible for a great deal of the new business promotion. Foreign capital was strongly limited and many companies were nationalised. These nationalisations took two forms. On the one hand, "nationalisation" strictly speaking meant the transfer of property rights from private enterprise to the state-owned firms. On the other hand, in a broader definition, "nationalisation" meant the process through which the property of a private foreign company followed into the hands of a private firm whose capital was in the majority hold by Spanish capitalists. What were the consequences of Franco's autarkic policy?

The state intervention after the Spanish Civil opened an era of small and less competitive firms; definitively smaller than the large previously private ones. The inheritance of the Francoist period marked and shaped the nature of Spanish business development. This inheritance was reflected in economic, political and social fields; in the regulating and legislative framework, of labour relations and, most importantly, in the development of a managerial and business class influenced for too long by bureaucratical restraints and military officials of the dictatorship. All this consequently isolated Spain from its European neighbours.

\section{State Entrepreneurship: the intervention of the INI and the emergence of the Spanish motor industry (1945-54)}

The period 1945-1954 was marked not by the elimination of the existing controls and moves towards a more open regime once the world war ended, but by their strict maintainment for further years. Economic activity was clouded by the scarcity of raw materials and basic intermediate products, and no fuel. The rise of publicly owned and managed firms after 1940 ("national firms") meant an effort to diffuse new organizational techniques borrowed from Germany and Italy and geared towards economic autarchy. Only in the mid-1950s, and after the failure of the previous autarkic strategy, American-oriented organizational techniques were diffused among Spanish firms. 
In their quest for autarky, the Spanish authorities adopted a set of policies with regard to industry which included the regulation of private investment, the foundation of public sector enterprise, quantitative restrictions on foreign trade and the manipulation of the exchange rate [Donges 1971: 48]. However, the failure of the Spanish industry to effectively respond to government measures convinced the policy makers of two factors. Firstly, they were firmly resolved that the market was an ineffective mechanism for the allocation of resources. Secondly, that Spainish entrepreneurs lacked business acumen. Thus only through state intervention, it was believed, could the country achieve the goals of self-sufficiency and rapid industrialisation.

Evidence of the shortcomings of the Francoist regime's industrial strategy has been provided by data on factory size. Donges has showed that, on the eve of the Stabilisation Plan, Spain's industrial structure was dominated by a large number of tiny enterprises, which comprised eighty five per cent of total industry [Donges 1971]. Even in such sectors as chemicals, basic ferrous metals, machinery and equipment, where the optimum size of firms was generally considered to be over a thousand workers, there was still a predominance of small concerns. Moreover state intervention, linked to the structural transformations of the Spanish economy, caused profound changes in the sectoral composition of large companies. The large Spanish firms became smaller with respect to their counterparts. The motor industry is a case in point.

Politicians, policy makers and military sectors had agreed on the need to industrialise the country and the motor vehicle industry was a priority target. However, to a certain extent, the plans of the newly formed regime had already put forward by Primo de Rivera during the second half of the 1920s, and were simply the culmination of past initiatives. Indeed, they did not differ very much from those of Primo de Rivera's period that never were put in effect. Moreover, the partial nationalisation program might be seen as a continuation rather than an interruption in the path to full motorisation. ${ }^{3}$ As Table 2 illustrates, first, there were projects that might suit the autarkic policy of the regime regardless of their economic efficiency (that is, a closed economy). And, second, there also were those projects that could be undertaken in open competition with foreign concerns (open economy). ${ }^{4}$

\section{Table 2. Activities to be undertaken in Spain according to market and production} possibilities.

$\begin{array}{lcc} & \begin{array}{c}\text { Protectionism. The } \\ \text { pursuit of autarkic goals } \\ \text { regardless of cost. }\end{array} & \begin{array}{l}\text { Without Protectionism could be } \\ \text { undertaken in competition with } \\ \text { foreign concerns }\end{array} \\ \begin{array}{l}\text { Small Cars } \\ \text { Luxury Cars }\end{array} & \mathrm{xx} & \text { No } \\ \text { Heavy Trucks } & \mathrm{x} & \text { Yes } \\ \text { Buses } & \mathrm{xx} & \text { Doubtful } \\ \text { Source: INI Archives, Madrid } & & \text { Yes }\end{array}$

\footnotetext{
${ }^{3}$ In order to promote a samll core of national manufacturers, the law of the Protection of the Automobile Industy was passed in 1927. Then, the Republican Government decided to to dictate several conditions in order to ensure at least a partial nationalisation. This partial nationalisation of manufaturing meant that local manufacturers supplied materials of more weight and lower level of manufacture. At the end of the Civil War, there were in Spain small workshops manufacturing all the parts of the vehicle, including motor engines. See Estapé-Triay (1997a).

4 "Notas de W.P. Ricart sobre la industria del motor en España", Ministerio de Industria y Comercio, January 4, 1946, Expediente Planell/CETA, INI Archives, Madrid.
} 
The first references of governmental regulation of the Spanish motor vehicle industry appeared together with the first attempts to reorganise the Spanish economy after the Civil War. Nevertheless, there had already existed a brilliant but small manufacturing activity in the previous decades. Thus, the achievements of that period were not at all wasted. Rather, they were the seed of the productive and technological infrastructure that facilitated to some extent expansion during the second half of the century. ${ }^{5}$

It is possible to distinguish several phases of government regulation regarding the motor vehicle industry. First, with regard to industrial activity until 1936, the Civil War meant a disruption of the activities and development achieved during the first decades of this century. Moreover, the new trends in mass production and mass consumption associated with the industry made it impossible for the small and artisan based Spanish producers to keep up. Spain had no firms at all of sufficient size. Moreover, its enterprises were not using modern methods of production to face the foreign challenge. The political economy of the industry was run within a protectionist framework. ${ }^{6}$

Secondly, within the frame of the 'Industrial Law Regulation' between 1939 and 1941, an industrially normative system was established with two objectives: a long term interventionism planning, and second, import substitution or autarky. Both objectives according to Farre were coherent with Spain's international political isolation, the destruction of its internal productive system and its economic distancing from Europe right at the beginning of the Second World War. The law of 'Industries of National Interest' of October 24, 1939, established the incentives to the investments of those activities considered as strategic for the national economy with the use of classical instruments such as tax benefits, grants and market quotas. The other important law, as seen elsewhere, was the one that created the National Institute of Industry.

Nevertheless, a different pattern was followed by the manufacturers of industrial vehicles due to the existence of a well developed technological sector. As a consequence, it provided the development of a supply and service industry. An important concern of the state leaders was the manufacturing of trucks because there was a great need for them since the end of the war. In this regard, two different options were under study. On the one hand, the establishment of a manufacturing enterprise from the remaining assets and facilities of the Hispano Suiza of Barcelona, by changing the former board of management and directors. On the other hand, the establishment of a completely new concern. The former was the quickest and cheapest solution. By acquiring the old facilities (incomplete and old-fashioned) as an initial core that could be increased and completed with new facilities, the company could immediately undertake the production of trucks and buses. However, in order to carry out such a plan it was necessary first, to change the actual 'mentality' or 'corporate culture' that was running Hispano Suiza, that in the light of experience was totally divorced from the standpoint of a rigorous industrial policy, and second, that any other activity related with air engines, weapons, etc. had to be promptly discontinued, because it was already insufficient for the production of trucks and buses. Third, regarding financial needs, an initial investment of fifty to seventy million pesetas for the modernisation of the means of production was recognised. The

\footnotetext{
${ }^{5}$ From a wider historical perspective, Spain was able to enter in the 1980s as the fourth European car manufacturing country with a production fully multinationalised as well as with a complex infrastructure of services and suppliers for the industry. This occurred despite the absence of its own technology. See Farré (1986:27).

${ }^{6}$ Royal Decree of December 3, 1926 that established the concept of national manufacturer and to be awarded a certificate.
} 
whole program would be run by a team leader composed of fifteen to twenty collaborators of a leading industrialist, W. Ricart. ${ }^{7}$ This team, whose members were considered to have the highest technical and industrial skills, were already familiar with mass production at Alfa Romeo. ${ }^{8}$ As regards the second possibility, i.e. not taking into account the workshops of Hispano Suiza, the program in its general lines did not vary very much from the aforementioned. The initial capital was planned to be around 150 million pesetas. In both cases, yet more especially in the second, it would have been necessary to set up workshop-schools to train the workers in the use of modern machine tools.

During the 1940s the Spanish state, through the intermediary of the INI, had made definitive attempts to develop a national automobile industry with the establishment of ENASA for the manufacturing of trucks, and the agreement with Fiat for the manufacture of light cars. ${ }^{9}$ Consequently, Ford Motor Ibérica's (FMI) future plans in their aim to maintain their organisation and to continue developing their normal activities were based on the possibility of arousing the interest of the Spanish government in the co-operation which they could offer in solving the difficult problem which Spanish agriculture was being confronted with for many years. They felt that if they could convince the Spanish authorities that they could become a decisive factor in solving the deficiency of farm machinery, they would in compensation, receive in the automobile field preferential treatment. FMI felt it deserved a preferential treatment because, Ford had a long history in Spain, had taken the lead in developing Spanish automotive parts industries, their social policy, etc. Together with the fact that their prices for the 8 HP and $10 \mathrm{HP}$ cars were the lowest, these facts would be taken into account in mobilising the government's good will towards Ford. Although the prospects of greater activity in FMI's plant were better owing to the trade agreement signed by Spain with England and France, which provided for the importation of substantial quantities of cars and trucks, they felt, however, that something had to be done to provide steady work for the plant in keeping with their past performance and long establishment in the country.

An approach to the authorities with an offer to manufacture the Fordson Major in Spain by supplying appropriate machinery and equipment payable with FMI's own currency, therefore had a good chance of being favourably received. It must be borne in mind that FMI had entered negotiations with the Ministry of Industry and Commerce to join in with the INI in the manufacturing of the truck, and after two years of discussions they had refused the proposal, for various reasons. First because they did not think that the enterprise would be financially sound and second, because they did not want to accept being controlled by the INI. ${ }^{10}$ The scheme sponsored by the Spanish Government

\footnotetext{
${ }^{7}$ Wifredo Ricart had a long tradition of involvement in the Spanish automobile industry. He had moved to Italy where he worked for Alfa Romeo. Then, with the new industrial policy of the Francoist regime, he was called to lead the establishment of the domestic motor manufacturing industry. He position was as an adviser to INI. According to Suanzes, president of the public holding, Ricart had been "entitled to direct all the plans for the manufacturing of trucks and engines in Spain" see letter Sirvent to Planell, Madrid August 3, 1946. Exped. Planell, INI Archives, Madrid.

8 "Notas de W.P. Ricart", Exped. Planell/CETA, INI Archives, Madrid.

${ }^{9}$ The INI decided soon to initiate motor vehicle manufacturing. Its plans are gathered in the following documents: See folders 243 (year 1942); 355,5 (1942, 1943, 1944, 1947, 1948) INI Archives, Madrid.

${ }^{10}$ The scheme sponsored by the Spanish Government under which the INI had been formed for the purpose of assembling motor vehicles, all the components for which were to be manufactured in Spain. The Spanish Government wanted to enlist the aid of Ford in this matter and Cooper, President of the Board of Directors of FMI, had said that every possible assistance could be given but that the Ford organisation was not prepared to introduce capital into such a venture. He was convinced that the
} 
under which the INI had been formed for the purpose of assembling motor vehicles, all the components for which were to be manufactured in Spain. The Spanish Government wanted to enlist the aid of Ford in this matter and Cooper, President of the Board of Directors of FMI, had said that every possible assistance could be given but that the Ford organisation was not prepared to introduce capital into such a venture. He was convinced that the project outlined could not possibly survive world competition and he also was of the strong conviction that the problem was being approached from the wrong angle. The considerations which had brought him to this conclusion was that the future world pattern was exceedingly uncertain and the United States were anxious to abolish barriers to international trade and would strongly oppose any import duties designed to foster home manufacture. The local manufacture of components was profitable only if the cost was less than the landed cost of import parts. Even allowing for CIF margins, Spain was not in a position to produce as cheaply as America and, therefore, the local manufacture of complete motor cars was not a sound proposition. Cooper thought that the Spanish government, which was not experienced in the manufacture of motor vehicles, had to be advised accordingly. He did not believe that the major competitors of Ford would have been prepared to support a scheme such as the Government proposed. In this regard, the local general manager said that throughout Spain there were a number of ordnance factories which, as they were not producing, were merely accumulating costly overheads. In Cooper's view, the obvious solution was that the Spanish Government should turn these factories over to the production of those components which could be produced more cheaply than they could be imported from America. The existing FMI plant could then be used to assemble vehicles from parts provided partly by Spain and partly by America. But it was unsound to expect FMI to purchase locally made parts at a higher price than that at which they could be imported. Only a reasonable proportion of the overheads incurred by ordnance factories should, therefore, be added to the price of locally manufactured parts.

Therefore, Ford had to be prepared to face an attempt from the INI to interfere with the new proposal, because according to existing laws any enlargement of activities or establishment of new activities by any existing concern had to be authorised by the Ministry of Industry and Commerce. A very important reason why this was necessary besides complying with existing laws was because the Ministry was deciding on the

project outlined could not possibly survive world competition and he also was of the strong conviction that the problem was being approached from the wrong angle. The considerations which had brought him to this conclusion was that the future world pattern was exceedingly uncertain and the United States were anxious to abolish barriers to international trade and would strongly oppose any import duties designed to foster home manufacture. The local manufacture of components was profitable only if the cost was less than the landed cost of import parts. Even allowing for CIF margins, Spain was not in a position to produce as cheaply as America and, therefore, the local manufacture of complete motor cars was not a sound proposition. Cooper thought that the Spanish government, which was not experienced in the manufacture of motor vehicles, had to be advised accordingly. He did not believe that the major competitors of Ford would have been prepared to support a scheme such as the Government proposed. In this regard, the local general manager said that throughout Spain there were a number of ordnance factories which, as they were not producing, were merely accumulating costly overheads. In Cooper's view, the obvious solution was that the Spanish Government should turn these factories over to the production of those components which could be produced more cheaply than they could be imported from America. The existing FMI plant could then be used to assemble vehicles from parts provided partly by Spain and partly by America. But it was unsound to expect FMI to purchase locally made parts at a higher price than that at which they could be imported. Only a reasonable proportion of the overheads incurred by ordnance factories should, therefore, be added to the price of locally manufactured parts. 
allocation of raw materials, which was vital to any manufacturing enterprise. No production of any kind was possible without the full support of the authorities and the preferential allotment of all raw materials. The following ideas were therefore submitted to implement a program of future development in Spain: in two of the three basic groups of Ford's products -cars, trucks and tractors- the Spanish government was already partly committed with FIAT and Spanish investors to manufacture light cars and also possibly light vans, and with ENASA for the manufacture of a heavy type of truck. However, no definitive arrangements had been made to manufacture a medium truck in the two to four ton category nor for a medium sized passenger car. Furthermore, no definitive commitments had been made or disclosed to manufacture tractors.

Ford Iberica's plan therefore called for specific models in each of the three basic groups mentioned. Tractors and other agricultural machinery were taken to prepare the ground with authorities for the other two. The Spanish government was conscious of the necessity to mechanise agriculture. The era of low farm wages in Spain was about to finish and the need for increased output of foodstuffs was imperative. It wanted the figure of 1,200 working tractors, to reach 2,000 or more in the near future. As regards cars, with difficulties in obtaining and paying for petrol products, Spain had had to ration gasoline and lubricants for automotive and industrial use. As a result of this and of the system of taxation based on horse power rating, cars of low horse power were being given preference by government and by private users. That Dagenham made passenger vehicles which were classed at 8 and 9 HP units respectively, appeared much more promising. These cars cost less to buy and to operate and had the advantage of being purchasable in pounds sterling, which although scarce, were not quite so difficult to get as dollars.

Therefore, assuming FMI's relations with the Spanish government were re-established on a more favourable basis as a result of an agreement over tractors initially, and on truck development on a longer term basis, they should aim to get as part of the overall arrangement a larger share of imports of British cars which, if obtained in sufficient quantities, would have placed FMI in a position to resume local assembly of the chassis only, for which they were already prepared, and for body frames to be brought in white to be trimmed and painted there in Barcelona. Local body frame assembly could be taken up latterly. A general understanding with the government about Ford's future activities in Spain was an indispensable condition of its development in the light car field. Parallel to the local passenger car assembly would have been the creation of sources of supply of local parts to integrate these units. Such items as batteries, wheels, tires, radiators, chassis and seat springs, front axle, hubs, mufflers, trim, glass, paint, etc. could then be purchased in Spain, as they were in pre-Civil War days. In the more distant future lied the possibility of making an engine which could be used to fit into a medium priced car in the 14-16 HP range for which there was a good market in Spain and would not have competed with the 9 HP passenger vehicle which INI and FIAT had agreed to build cooperatively in the country.

The home office did not give, however, support to the proposals of the subsidiary. They argued that the prospective volume was not sufficient to make them a sound longterm economic proposition. Secondly, in their opinion Spain's foreign trade especially with the UK, was likely to improve and it would probably be able, before long, to import automotive products from the UK, at a price much below the local manufacturing cost which could be attained from Spain's limited volume potential. Third, Ford was not inclined to engage in a joint venture for local manufacturing; to do so would 'morally' commit Ford to continue financial assistance if and when the locally manufactured 
products could not compete with imported products. In conclusion, the home office recommended the Barcelona firm to develop the company's established policy of maximum local purchase, so long as this was profitable. ${ }^{11}$

During the period 1945-54, Ford Motor Company was facing nationalistic pressure in Spain. The consequence was that finally, in May 1954, Ford Dearborn sold its participation in the Spanish company to local interests. Ford US had argued that the size of the market and various other factors made it impossible to continue in Spain. However, the reality seemed to contradict this opinion. In effect, the year 1954 constituted a turning point in the Spanish motor industry. When Ford left Spain, SEAT was constituted and from then on the Spanish motor industry saw a remarkable increase. Other foreign companies such as Renault and Citroen set up concerns in the country. What seems to be one of the main reason for Ford's departure were the limited opportunities left in the business field to Ford: the tractor and light truck were unattractive to Ford Motor Company. On the other hand, another important consideration preventing Ford from engaging in local production, as pointed out by Wilkins and Hill, was the insistence of the government that a controlling interest in any joint venture should rest in Spanish hands. This stipulation was disliked by the Ford top management in Dearborn, which felt that even a majority interest in its foreign companies was unsatisfactory and wanted a hundred per cent ownership in all of them. ${ }^{12}$ Finally, though Ford Motor Company sold its subsidiary entirely to local capital, it nevertheless established commercial and technical agreements with the new 'national' company, Motor Iberica. Thus, the latter developed its products, trucks and tractors, with Ford's technical aid. Moreover, Ford preserved its Spanish commercial network that allowed the American company to sell its products through a well established sales network. ${ }^{13}$ Ultimately, the decision to leave Spain still remained profitable for Ford because it assured them at least ten years (according to the terms of the contract) of business in the country.

To conclude, it stands clear that our case study fits in with recent studies that stress the negative consequences that state decisions of this period produced in the long run. In effect, the intentions of Ford clashed with those of the Spanish government, for the economic nationalism of Franco presented government's interventionism in car manufacture as the only possible alternative for the production of automobiles in Spain. As San Roman has pointed out recently, SEAT was for a long time considered the prototype of the paradigmatic company of Franco's regime. ${ }^{14}$ The incapacity of private enterprise was the main argument used to entrust the car industry to the INI. The INI used its power to block any private initiative and assume the creation of the first national mass production motor vehicle company as its own. Within the car industry, the INI did not protect national companies but, on the contrary, defended its own projects. Although Spanish national attempts during autarky were scarce and small, both General Motors and Ford presented their projects for the building up of a national industry. The reaction against foreign capital and the defence of "national", "sectarian" and "patriotic" interests prevented Spain from developing a modern industry earlier. As a contemporary observer pointed out, "an apparent government policy which upon control by INI of all new

\footnotetext{
11 'Conference at London Cooper, Claridge Elliot and. Ubach). "Manufacturing Proposals." 12 November 1948, Box 7534, in \# Visit Dagenham 1947-48, FMI Archives, Barcelona.

${ }^{12}$ Wilkins and Hill (1964: 402).

13 The definitive separation came in 1967 when the Spanish company established an agreement with Massey Ferguson by means of which the latter acquired a $36 \%$ participation of the former.

${ }^{14}$ San Roman (1995: 141).
} 
automobile developments in Spain, has been the stumbling bloc which has been preventing big concerns like Ford and General Motors from operating on a major scale in Spain. In effect, INI prevented the establishment in Spain of any major motor vehicle industry it did not control." 15 In this regard, after the establishment of the industrial legislation frame between 1939 and 1941, two decisions were taken in order to develop in the medium and long term a national motor vehicle industry. First was the creation of the "Empresa National de Autocamiones, S.A." (ENASA) in 1946. This firm was created from the remaining assets and the human and technological capital of Hispano Suiza. The second decision was the creation of the "Sociedad Española de Automóviles de Turismo" (SEAT) in 1949. The INI capital participation in Seat was one third, the rest was divided in two, tin which Fiat held one third and private Spanish capital held the other. Fiat provided the technological assistance. These two firms replaced the American multinationals with the declared objective of substituting imported cars. The establishment of SEAT was immediately followed by Fasa (1951), a branch of Renault. A market so extremely protected and short of goods as the Spanish will attract foreign manufacturers in the following decades.

\section{Comparative perspectives. The cases of Egypt and Brazil}

Spain was not the only case where Ford was facing nationalistic pressures during the decades of the 40s and 50s. For example, in Egypt, from 1945 on, Ford found itself in an increasingly restricted political and financial environment, which its executives were not able to dominate. Ford's investment decisions had to take account of nationalist sensitivities and could not be based on purely economic and financial realities. The decade and a half from 1945 to 1960, thus serve as a test of how well Ford fared in its relations with an increasingly nationalist and watchful Egyptian government. The emphasis on Egyptianisation was made palpable by the enactment of a 1947 law that imposed a number of requirements on firms operating in Egypt, including, of course, the Ford Motor Company, which in spite of being completely owned by Ford Investment Company, was juridically an Egyptian limited liability company. For new firms, the law stipulated that at least 51 per cent of a company's equity capital had to be offered to Egyptian nationals and 40 per cent of the places on their Board of Directors be Egyptians as well. In spite of this, Ford remained optimistic about its future in Egypt. In 1950, it established a new and larger plant in Alexandria. This move came about because General Motors and Chrysler were also planning to established themselves in Egypt. Until the 1952 coup, Ford Egypt had fared well in an environment of strong nationalist sensitivity. It had used its affiliates and business connections around the world to overcome currency restrictions, and though its divided and currency negotiations with Egyptian bureaucrats had not been easy, they had been satisfactory. However, after 1956, the pressure on all private businesses increased greatly. Nor did Ford have its way on its two most important business decisions of the late 1950s. In 1957, it contemplated liquidating its Egyptian business, but was forced to conclude that the financial penalties likely to be imposed by the Egyptian government would be too punitive to make this outcome possible. Later in 1959-1960, it made an offer to create an automotive manufacturing plant in the country. It did so because the company was on the defensive vis-à-vis an

\footnotetext{
${ }^{15}$ Knoblaugh (1949: 25).
} 
increasingly regulatory and intrusive Egyptian government and wanted to show a willingness to participate in the local push to industrialisation. ${ }^{16}$

The development of the motor industry in Brazil is another interesting case. In 1956, the country had instituted a program to install an automotive industry. As Shapiro (1991) has illustrated the plan restricted imports and forced multinational automotive companies to choose between abandoning the lucrative Brazilian market and, with the help of financial incentives, producing vehicles with 90-95 per cent Brazilian-made content within only five years. Although cars and trucks had been assembled in Brazil since 1919 -when Ford was the first to set up an assembly plant, followed by General Motors in 1925- the industry remained completely dependent on imported kits, primarily from Detroit. Ford had no intention to produce motor vehicles in the country. Before the Second World War, the company dominated Brazilian passenger car sales; between 1935 and 1940, annual exports from Ford US and Canada averaged 42 percent of wholesale deliveries into Brazil. Because of Ford's historic contribution to the automotive sector and its market dominance, the Brazilians went out of their way to elicit the company's co-operation. Ford's local management had also tried to impress on Dearborn the seriousness of Brazilian intentions. The government asked Ford-Brazil for a report on how Brazil might develop a local industry, and the Brazilian assistant manager, complied. Ford Dearborn adopted an intransigent position from which it scarcely deviated in the following years. In February 1953, for example, the director of President Vargas's subcomission on motor vehicles, led a Brazilian delegation to Ford's facilities in Dearborn. On its arrival, Ford did everything possible to convince them that producing trucks in Brazil made no sense because of the country's small market and lack of infrastructure. Being the first motor company to establish itself in Brazil and dominating the market, why did Ford not try to made more of it? Subsequent interviews with Ford managers of the period indicate that some viewed Ford's late entry as a mistake. In retrospect, they offer various explanations for Ford's absence from this market segment. Some attribute it to Dearbonr's lack of knowledge or interest in international affairs. Ford International, located in New York until 1956, was still somewhat of a stepchild in the organisation. Ford was not manufacturing in any less developed country at that time, and had recently sold its interest in Spain and liquidated in India rather than comply with the local capital requirements of those countries' automotive programs. Ford Brazil, though profitable, had been relatively marginal to Ford's overall operations. Ford had brought virtually no new capital into the country since it had begun assembling there thirty-seven years earlier. $^{17}$

\section{State Entrepreneurship and Multinational Enterprises (1955-1973)}

In the post-war year Spanish industrial expansion was hindered by insufficient production of electricity, shortages of steel and cement, lack of skilled labour and management, inadequate private investment, a level of foreign exchange earnings too low to cover imports of capital goods, and the autarkic bias of the country's rulers [Catalán 1995]. However, at the beginning of the 1960s, these weaknesses were overcome, and Spain's industrial pattern was transformed from one dominated by textiles into one in which the metallurgical, chemical and building industries, and power production were predominant. One of the main features regarding this process was when the year 1957

\footnotetext{
${ }^{16}$ See Tignor (1990: 387-8).

${ }^{17}$ See Shapiro (1991: 876-7).
} 
brought into government the team of technocrats who were to introduce a new economic policy to reconcile rapid industrial growth and its consequences. Moreover, foreign investment was encouraged by allowing the repatriation of profits, and the importation of advanced technology by permitting royalty payments. The goal was to shift the economy away from an inward looking country towards an outward looking one, where manufacturing sectors would play a major role. The automobile industry was called to play a major role in the economic boom of the 1960s.

The spectacular growth of the 1960s had been attributed to three main developments [Donges1971]. First, the trade liberalisation measures initiated in 1959 that encouraged the import of capital goods which in turn contributed to a renovation of much of Spain's outdated capital equipment. Second, the launch of a plan of action to promote the export of manufactured goods initiated in 1959 with the devaluation of the peseta. Moreover, among the main aspects of the new policy were the provision of export subsidies to producers, exempting them from paying indirect taxes on foreign sales, rebates of import duties paid on raw materials, spare parts and capital equipment used towards the production of exports, and financial assistance to exporters. Third, as highlighted by Donges, the external financing of Spanish industry reflected a profound change in official attitudes towards foreign private capital. However, later interpretations of Spain's industrial boom years argue that Spain's industrialisation policy in the 1960s was still resolutely protectionist. Foreign investment was of crucial importance to the industrialisation process, not least because of Spanish industry's unwillingness to undertake research and development [Braña, Buesa, and Molero 1984]. However, in the motor vehicle industry it was expected that the technological basis established in the industry would bring positive effects to other sectors. The technological requirements for automobiles would force technological improvements in related supply industries. Therefore, the automobile industry would raise labour productivity because of the its technologically trained workforce. In an attempt to tackle the long-standing weaknesses of the reduced dimension of enterprises, shortage of capital, technological backwardness and low productivity, Spain's policy makers pursued a strategy of industrial concentration.

As it has been abovementioned, the aim of the INI was to create the infrastructure for industrial development. In so doing, it invested public funds in those areas where, according to the public holding, private capital was unwilling to risk a low return or in enterprises which needed state aid to get off the ground. The automobile industry was an example of the latter: in the late 1940s, the INI set about establishing a broader-based automotive industry. For instance, during the forties the INI bought up the old HispanoSuiza: the new concern, ENASA, first embarked on the production of an expensive sport car, superbly engineered and presumably meant to 'fit' a domestic market dominated by a small number of the very rich. That this car was a commercial failure was less important than the fact that Pegaso became a mass producer of commercial vehicles. A spectacular growth subsequently took place in new industries, and as in all modern economies, the car industry provides a test case. When the SEAT factory was set up in Barcelona in 1952, its managers were concerned that the market might not absorb a hundred cars a month; by 1975 Ford, Chrysler, Citroen, Renault and Seat were producing three quarters of a million vehicles a year. However, these dramatic figures are in part a mere reflection of the abysmal point of departure in 1940 and the restrictive policies of the years that followed.

SEAT was brought into being to produce Fiat cars under licence. After Seat-Fiat, Fasa-Renault was the other major case in the development of the modern Spanish 
automobile industry. The government gave authorisation to Renault to set up a concern in order to produce the $4 \mathrm{HP}$ car. The type of car selected, the Renault $4 \mathrm{HP}$, was considered by the authorities a suitable one because it did compete directly with the Fiat 1400 that the new formed company, Seat, was about to produce. The establishment of the production program meant that Renault had to fulfil the following conditions. First, on initiating the assembly of vehicles in series it had to be guaranteed that the value of all materials and parts of Spanish origin or manufacture would represent at least twenty five per cent of the total cost price of vehicles. Once the manufacture was started assembly operation in series would not begin until an output of at least 200 cars per month could be assured, and sale of cars to the public would not be started until proof was given that $55 \%$ of the sales prices once finished with the plant corresponded to disbursements in Spain. Secondly, one year after the start of assembly, this 50\% threshold was to be raised to $70 \%$. Thirdly, three years after the assembly process had begun, and at the most, five years after the date of publication of the this authorisation, such a percentage was to be raised to $90 \%$ and engine, clutch and gearbox were to be comprised therein. Fourth, six years after the publication of the authorisation, production was to be made entirely in Spanish workshops. Finally, the supply of raw materials was subject to the local production programs of parts previously approved by the administration, taking into account the results reached in the local production of various parts, as well as the availability of raw materials in the country. ${ }^{18}$

The conclusion of the US-Spanish agreement signed in Madrid in 1953 encoured private investors. And, the economic reforms and the growth of tourism following the 1959 devaluation provoked a further wave of initiatives. Leyland had acquired shares in ENASA. BMC, in collaboration with Nueva Montana Quijano, had acquired a 20 hectare located near Pamplona for the production of up to 80,000 Minis, and possibly 1100s, a year. Renault had increased its share in Fasa, an associated company, from 15 to $50 \%$ and bought control of FAMESA, an important component manufacturer. Ford which held first place among importers (a close second, interestingly, was Czechoslovakia's Skoda), had during 1964 been discussing with Motor Iberica the possibility of producing its German-designed Taunus 12M. IMOSA was to make industrial vehicles in alliance with VW. It could be argued that the Spanish motor industry already sustained too many firms for its good health, and that concentration was needed to increase production runs, improve quality and bring prices down. SEAT (whose 600 and $1500 \mathrm{cc}$ models held $62 \%$ of the market), Fasa Renault and Enasa had political as well as economic reasons to be confident. And, in the private sector, Citroen ( $25 \%$ of the commercial market), Motor Iberica and Barreiros were firmly established. ${ }^{19}$

It has been argued that the Spanish state had for a long time gone in pursuit of a domestic industry capable of manufacturing a 'popular' car on a large scale basis. To this end, there was at the beginning of the 1950s a certain optimism, across Spain, regarding the possibility of producing automobiles. Several firms such as Eucort and Fasa had already undertaken the production of automobiles. ${ }^{20}$ This production, however, was

\footnotetext{
18 Direction General of Industry, Minister of Industry, 19 October 1951, Madrid Gazette num. 292, p.4723.

${ }_{18}$ Madrid Gazette no. 292, page 4723.

${ }_{19}$ See The Economist, 15 May (1965: 794).

20 "Solicitud de industria de interes nacional por Eusebio Cortés de Automoviles Eucort" Seccion 242, Legajo 4 (1946), INI Archives, Madrid; "expediente Renault" Seccion 242, no.0 (1947), INI Archives, Madrid; "Expediente Manuel Gomez Alfaro (Fasa)" Seccion 355, (1950/51), INI Archives, Madrid. On Eucort see also San Román (1995: 156-8).
} 
carried out by the assemblage of parts supplied by a multitude of small local workshops. It is worth noting that the major part of these workshops did not posses modern means of mass production, rather, it was the case that all of them lacked the means and skills for such a kind of production. Conversely, according to Ricart, the chances of developing an industry locally that could be technically advanced and economically efficient depended on a different strategy. ${ }^{21}$ In effect, according to him it was first necessary to develop a supporting network of ancillary industry. This would absorb much of the work that would otherwise have gone to only one factory; in this sense, ENASA was considered an example to follow. Second, apart from a few cases, notable but exceptional, the Spanish ancillary industry was not ready to supply a modern large scale manufacturing industry mainly because of the quality deficiency of its products (dimensions, technological treatment of production); and secondly, the weak and outdated capital equipment, technically backward and with prices incompatible with those required by a modern motor industry. In effect, during the years of scarcity and isolation, the workshops that produced spare parts were used to do so selling low quality products at high prices.

Italy, for example, a country to a certain extent comparable to Spain, had developed a truly modern motor vehicle industry. In effect, $99 \%$ of its production was carried out by Fiat, Bianchi, Masseratti, Ferrari, Alfa Romeo, Lancia, and O.M. All of them possessed complete manufacturing workshops. ${ }^{22}$ In Sweden, for example, the state had given all kinds of advantages to Scania-Vavis and Volvo; both of them were producing all sort of motor parts in their workshops and importing just the 'proprietary units' (generally from the US) that they still were unable to produce by themselves. ${ }^{23}$ In Spain, ENASA had managed to increase the quality of the automobile electric equipment that had since been produced in low quality but production was not on a large scale basis. Its efforts were towards the consolidation of some specialised mass production industries in clutches and shock absorbers. Moreover, both the CETA and ENASA had attempted to developed ancillary industry and produce gear boxes and brake systems locally, however, without any success whatsoever. These negative outcomes had confirmed both the difficulty itself and the infant stage of the domestic mechanical industry. It was thought, therefore, that in order to be able to produce a 'popular' car on a large scale it was necessary to have rationalised workshops with modern purpose machine tools and with an enormous capital investment. In this sense, Fiat had established for SEAT a program based on the establishment of modern workshops.

To sum up, the manufacturing of a low price vehicle was only possible with the modernisation of the capital equipment and enabling high level of production. Second, in the limited Spanish market, with low levels of income (and therefore low purchasing power) and a low population, it was not logical to produce just for the domestic market. Production therefore had to aim at export markets equally. Finally, in a country with a low income per capita ratio, it was only possible to manufacture quality items with a high proportion of the workforce. It was their belief that Spain could undertake the production of specialised motor vehicles with a high ratio of workforce and then export them. ${ }^{24}$

After the period of big recession of the 1940s and, in part, the 1950s, a new state strategy more open to foreign capital, facilitated the creation of the modern Spanish

\footnotetext{
${ }^{21}$ Comunicacion CETA a Gerencia del INI. Asunto: Fabricación de Automóviles, S.A. de Valladolid, Expediente Manuel Gimenez Alfaro, 1951, Seat 355 1950/52. INI Archives, Madrid.

${ }^{22}$ On Italian auto industry, see for example, Fauri (1996).

${ }^{23}$ On Swedish auto industry, see Glimstedt (1995).

${ }^{24}$ On the Pegaso sport car see "The Iberian Flyer", The Autocar, 26 Sept. (1952:1189-91).
} 
automobile industry. It will be necessary, therefore, to introduce a bargaining framework of analysis that considers both state intervention and multinational enterprises in order to understand the development of this industry. Some decades later, at the end of the 1970 s, the industry had become dominated by multinational enterprises. ${ }^{25}$ Thus, in little more than a decade three more companies were created - producers of private cars and by-products Citroën Hispania (1957), Chrysler Barreiros (afterwards the Peugeot Talbot España, 1963) and AUTHI (1967), all of them subsidiary firms of multinationals Citroën, Chrysler (sold to Peugeot) and the British Motor Corporation. Finally, the map of the Spanish automobile industry was completed with the establishment of Ford Motor Company (1972) and General Motors (1979), both of them coming to Spain for the second time. ${ }^{26}$

Spain developed and expanded automobile production during the 1960s and 1970s from a set of based-owned firms and imported technology. The Spanish industry grew with extraordinary speed, from 50,000 passenger cars in 1961 to more than 700,000 in 1973 , an annual increase of nearly $25 \%$. This was the result of a young industry that was dominated by foreign manufacturers. Seat-Fiat and Fasa Renault were by far the largest companies in the period before 1973. Then, with its establishment in 1972 , Ford called for Spain to play a major role in its European operations. Nevertheless, it should be remembered that, although the modern industry has taken off in the second half of this century, it did not start up form nothing. All the developments from the very beginning of the century have timidly to be considered. The nationalistic policy after the Civil War caused distortions that particularly affected those firms already involved in the automobile business.

A subsequent period might be traced between 1945 and 1963 with the establishment of ENASA in 1946 and the creation of SEAT in 1949. Around 1950, a service and supply industry triggered by ENASA and SEAT began to develop. This first development after two decades fixed the basis for the further development of the industry in the 1970s and 1980s. Apart from the most relevant cases mentioned above, others attempts have to be considered such as that of Barreiros in the manufacturing of tractors, trucks, and buses. On the components side, it is worth mentioning the cases of Femsa (electrical equipment), Fraymon and Bendibérica (brakes system) and Perkins Hispania (diesel engines). ${ }^{27}$ This period also saw the appearance of several attempts at the manufacture vehicles from artisan methods, such as Eucort ${ }^{28}$ and Biscuter, as well as more serious cases of the first foreign multinational enterprises entering the Spanish market through the establishment of joint ventures with Spanish firms, such as Renault

${ }^{25}$ For other cases, especially in Latin America, see Jenkins (1977, 1984), Bennett and Sharpe (1985), Kronish and Mericle (1984), Shapiro (1994).

${ }^{26}$ The new Ford and GM firm of the 1970s and 1980s were completely different concerns from those of the 1920s, that is, there is no line of continuity between them. When Ford came to Spain, all the other firms already established were producing at high costs because series were not long enough and the productivity of the plants was too low. On the contrary, the new Ford factory was conceived to respond to the maximum internalisation of its products. The plant was designed to produce a single type of vehicle, the 'Fiesta', which was sold throughout Europe; GM did the same few years later with the Opel Corsa.

${ }^{27}$ Learning has often began via agreements with international suppliers of equipment. In the "healthy" scenario - which is not the rule - the international technology transfer agreement became more sophisticated, involving adaptation of plants and technologies to local circumstances, while the emphasis was kept on personnel training and learning by using. Finally, autonomous capabilities of plant upgrading and process engineering were sometimes developed. Cimoli and Dosi (1995: 260).

${ }^{28}$ San Roman (1995: 156-158). 
with Fasa (Fasa Renault), Massey Ferguson with Motor Ibérica, Citroen Hispania and Land Rover Santana. ${ }^{29}$

The next period covers the years 1963-1964. In the context of the First Development Plan (Primer Plan de Desarrollo), a new decree was proclaimed that established a regime of free installation, enlargement and transfer of some specific industries in Spain. For the first time, the law established economic, technical and size conditions for the settlement of industries in different sectors. In the case of motor vehicles, the production plant capacity was to be cars $(75,000$ units/year); trucks and buses (8,000 units/year); tractors $(10,000$ units/years) and motorcycles $(25,000$ units/year). All the vehicles produced within the first two years of manufacture were to constituted of a minimum of $70 \%$ of national component over the manufactured value of the vehicle. After the two first years, it should increase to $90 \%$. It states clearly that by that time there should exist the notion of an emerging industry with a high degree of national integration that had to go beyond the simple assembly industry as was the case with other emerging economies, mainly in Latin America [Bennett and Sharpe 1985; Jenkins 1977; Shapiro 1991, 1994].

In the midst of Spain's economic boom, several weaknesses were apparent. In effect, as a contemporary observer pointed out that Spanish private enterprise, reared in an autarkic hothouse, was not yet enterprise enough. The state owned sector was ill coordinated, had neither the weight nor the prestige of the great nationalised and semipublic industries which had contributed so robustly to economic progress in France. Excessive investment in real estate at the expense of manufacturing was one of the big pressure points in the economy. Another was the too rapid rise in government expenditure [The Economist 1966: 1275]. Some new industries had been set up with so much protection and government-backed capital that they could scarcely have failed commercially, but the real weakness lay in the unwieldy bulk of Spanish private industry built up before 1958. In a protected market where prices were controlled, there was little incentive to expand (except for favoured state enterprises); most profits before 1958 were therefore distributed and private industry became massively descapitalised. In those years before 1958, the Spanish commercial banks, and in particular the biggest eight, gained a stranglehold on financing industry. Statistics may suggest the stranglehold was being broken, but in reality all that the figures really show was that the major part of private industry was controlled by the banks who did not publish meaningful financial returns. Industry was still closely tied to over-geared bank capital [The Economist, 5 August 1967: 511].

During the period 1964-1972, a new minimum size of capacity was established for the automobile industry. This stood at 125,000 units/year for cars and, 12,000 units/year for trucks and/or buses During the first years of the 1960s with a period of general economic development, the Spanish market was beginning to be taken in to account by the European manufacturers who had finished with post-war reconstruction and had, therefore, an excess of capacity impossible to be introduced on to the Spanish market due to the protectionist legislation. Thus, several firms started to approach to the Spanish market: British Leyland, Chrysler and Volkswagen. This activities were still subjected to the conditions for national components, 70 per cent of manufactured value in the first year to be increased to 90 per cent in the third. The period came to its end with the

\footnotetext{
${ }^{29}$ By 1963 foreign capital and know-how were pouring onto the country. For example, this year saw the acquisition for $\$ 17$ million - Chrysler biggest foreign investment - of the shares of the truck manufacturer Barreiros. And Rootes went into partnership with Metalurgico de Santa Ana to make engines and commercial vans.
} 
signature of the 'Spanish preferential treatment' with the European Economic Community.

By the mid-sixties, Spain had become one of the fastest-growing markets for cars and commercial vehicles in the world: from only three cars per thousand inhabitants in 1950, the density had grown to twenty-one per thousand, or a total of around 700,000. Moreover, while imported vehicles, paying customs duties of over 60 per cent, accounted for only eight or nine per cent of current sales, domestic production, almost entirely in joint ventures with foreign multinational manufacturers, was being expanded rapidly. ${ }^{30}$ Exports had expanded rapidly. For instance, SEAT had had great success in exporting the Fiat models which were no longer made in Turin. Renault was making its R4 and R8 in Spain, after they had been phased out in France. And Citroen produced its GS in Spain for export to non-European markets. SEAT (55\% of the market) increased production to 500,000 cars a year by 1976 . Renault ( $24 \%$ of the market) reckoned on 200,000 within three years.

In conclusion, as regarded the first specific regulating activity for the automobile industry, the main characteristics of the motor vehicle industry in Spain at the beginning of the 1970s were as follow: first, production mainly destined to the domestic market under severe protection against imports; Second, a high degree of nationalisation as a consequence of both the strong integration of the manufacturers and the existence of an important auxiliary industry; Third, complete external technological dependence.

\section{Organisational developments (1955-1973)}

After the stagnating 1940's, the creation of the "Comisión Nacional de Productividad" (National Productivity Commission) in 1952 and, just afterwards, the by-products of the USSpain military agreement of 1953, opened a new period. For some twelve years the activity of managerial retraining and of professional development was very much intensified. Many "productivity missions", public grants, new committees, new specialized journals and, eventually, even new management schools, built new managerial capabilities in Spain's business world [Herrero, 1990]. The main paths for the introduction of new management techniques were the consulting firms. They used to be of French or US origin, and the first to operate were created in 1952 (TEA) and 1953 (Bedaux).

By 1960, De Miguel and Linz observed the emergence of a new pattern of specialized management in a large sample of in-depth interviews with business leaders [Linz \& De Miguel, 1963; De Miguel \& Linz, 1964]. Their sociologically oreinted enquire allowed the first major collective photograph of the business world with a lot of attention being payed to the management of human resources and to internal organization schemes.

More than through schools, programs, grants, journals and consulting firms, Spanish entrepreneurs and managers have been exposed to large and efficient business organizations mainly through contact with multinational firms. They began to land in Spain by the end of the 1950s. Just when Ford abandoned Spain, other automobile manufacturers (French ones) began to think of investing in Spain. The set of international economic agreements subscribed by the Spanish Governement between 1958 and 1962, and the passing of a law accepting foreign capital majority for the new investments, induced international capital to flow to Spain. The amount of foreign investment was really huge in Spanish terms and in very few

\footnotetext{
${ }^{30}$ The Spanish government had announced new and easier rules for foreign car firms: only 50 per cent of the components needed to be Spanish-made in place of the previous 70 per cent minimum. Ford had recently been diversifying some component orders to Spain that used to be placed in Britain. Chrysler, Fiat and even British Leyland had been buying more Spanish components.
} 
years the enterpreneurial landscape changed completely. The multinationals landed very quickly into the newly opened country. In no more than twelve years, their presence became so important as to be perceived as a danger by a new generation of nationalist leaders [Roldán, Muñoz and Serrano, 1978]. The professional careers of top and middle managers happened in foreign-owned firms. They represented newly arrived capital, with expansion plans and new organizational, marketing and industrial techniques. They were much more willing to value academic training and foreign language abilities than the old fashioned national firms. Slowly, but firmly, Spanish managerial talent was located and promoted by multinational firms. A market for managers developed and it was useful even for familyowned or state-owned firms -the two most reluctant antimanagerial groupings in the business world.

Family-controlled firms have been cautious in their organizational growth, mainly in manufacturing. There still are many family firms of medium and even large size. Most of the firms that are not quoted in the stock exchange are family-owned. "El Corte Inglés" (the Spanish leader in sales) is the most famous one, but not the only one. The lobby "Instituto de la Empresa Familiar" (Family Firm Institute) was created precisely to group many of these medium and large size firms that are mainly worried with sucession law and with the passing of ownership from generation to generation and that survived the arrival of foreign capital in the sixties, the labor unrest of the seventies, the industrial crisis of the eighties and the weight of the welfare state in the nineties. For them, organizational growth has always been problematic. Some have bet for quick internationalization, but on small niches of the world market, feasible to supervise. Some have accepted growth, but depending on a very loyal group of middle and top managers, partly payed with company shares.

Most of the manufacturing firms that do no qualify as family-owned, are branches of multinationals or will become so. Many arrived to Spain during the period 1960-1973 and from 1985 to 1992. There were also very signicant transfers of ownership from Spanish families or shareholders to international groups. Each liberalization has meant a tremendous challenge to the more inward-looking Spanish firms. The opportunity to jump to an open market or to jump to European markets existed, but huge financing and proprietary technology was needed. The risk was high and there were many cases of shareholders prefering to sell their lot at a very attractive price instead of betting for a very risky future.

The rise of multi-divisionally Spanish-based firms was slow. There is nothing like a clearcut success story of the development of multidivisionalization in Spain. The large pre-war firms were functionally developed, but were far from becoming multudivisional. After the war, most of them had to reduce their activities. The Bank of Spain, heavily involved as private firm into the management of the C.A.Tabacos, lost it. The mining firms were under pressure to open its shareholdings to Spanish interests. Others were nationalized. Only big banks increased their size, and their industrial investments created something like a multidivisional organization. In the early 1960s, a law was passed that enabled banks to divide their activities into commercial banks and industrial banks, easing the monitoring of their more risky, long-term business interests.

Not even the INI created a multidivisional structure [Martín Aceña \& Comín, 1990]. The variety of industrial sectors where the INI was present forced the emerging of a real organizational investment. Patterns of complex organizational patterns developed during the forties and fifties. As long as Suanzes chaired the INI, this investment had a well-defined goal. Its major strength was the impressive length of service of the main top managers (fifteen to twenty-five years!). But after his dismissal, in 1963, the following presidents managed the INI without any clear goal in mind. The end of the autarky dream was also the end of the "raison d'être" of INI. The new chairmans concentrated their efforts in improving 
the organizational structure, and a real multidivisional structure slowly emerged. Its first complete picture was defined and approved as late as 1976, after the death of Franco and when the INI became fully managed by specialized managers.

The high rates of growth of the 60 s and early 70 s allowed a few Spanish industrial firms to plan a multidiviosional development. We know of two clear cases in point: Altos Hornos de Vizcaya (AHV) and Unión de Explosivos Rio Tinto (UERT). The former, a steel works created in 1901 through merger, was for half a century the largest Spanish steel making firm.

AHV resisted pretty well the increased competition of newly created large state-owned firms like ENSIDESA, and managed to modernize its assets during the 60s with the technical and financial help of US Steel. By 1970 AHV was emnbarked in a intense industrial diversification, developing brand new divisions. The industrial crisis of the mid-70s stopped it. For two decades AHV has been involved in an implosive trend that has eventually brought the firm to complete disappearance. UERT was the outcome of the nationalization of Rio Tinto (Cía. Española de Minas de Rio Tinto) plus its merger, in 1970, with the chemical firm Unión Española de Explosivos. The resulting firm decided to fully exploit its economies of scale and scope and began to buy firms that brought to UERT complementary branches of activity in the chemical sector. By the late 1970s it organized in a multidivisonal way. Nevertheless, the internal reorganization was too limited to cut down costs and to allow UERT to survive in a an ever increasingly competitive environment. The oil second crisis of 1979 was fatal for UERT. The early 1980s were a financial desaster for UERT. The landing of the Kuwait Investment Office in Spain, mostly oriented to chemical investment, brought a solution to UERT headaches: a merger with Cros, creating ERCROS, and the selling of most of its non-chemical divisions. The downsizing was completed during and after the Kuwait war, when KIO began to withdraw from its Spanish interests.

\section{Conclusion}

The changes in regime (political, economical, legal) have meant major alterations in business ownership and in organizational strategies. This happened in Spain many times since 1930. The civil war, the autarky, the liberalization of 1960, the oil crisis shock and its aftermath (industrial and banking crisis), coupled with the shock of the change in political régime and its social counterpart -the increased strength of trade unions-, theentrance in the EEC, ... all these have been major changes in régime, sharply felt by Spanish-centered firms. The outcome has been the inability to build adequate organizational structures. Each period has promoted a particular kind of organizations and managers that may have been completely unfitted for the following period. The managers educated to deal with trade unions in the 1930s were of no use in the 1940s when trade unions were completely illegalized. Those ideally suited to the military-engineering approach of the autarky were a disaster for the new market-oriented era of the 1960s. Both were unable to resist the years of high trade-unionism during the transition to democracy period (1973-1978) and of soaring energy costs. Even the new class of young managers has not found easy at all to survive in the more competitive business environment post-1986, when Spain entered into the EEC.

\section{Bibliography}

Ballestero, Alfonso (1993), Juan Antonio Suanzes, 1891-1977. La política industrial de la posguerra, Lid, León 
Bennet, Douglass and Kenneth Sharpe, "Agenda setting and bargaining power: the Mexican state versus transnational automobile corportations", World Politics, 32 (1979)

Braña, Javier, Mikel Buesa and José Molero, El Estado y el cambio tecnológico en la industrialización tardía: un análisis del caso español (México, Fondo de Cultura Ecnómico, 1984)

Carreras, A. and X. Tafunell, "La gran empresa en España (1917-1975): una primera aproximación" Revista de Historia Industrial 3 (1993)

Carreras and Tafunell (1997), "Spanish Big Firms, between State and Market, 1917-1990", in Chandler, Alfred D., Amatori, Franco \& Hikino, Takashi, eds. (1997), Big Business and the Wealth of Nations, Cambridge U.P., New York.

Catalan, J.La economía española y la segunda guerra mundial (Barcelona, 1995).

Cimori, Mario and Giovanni Dosi, "Technological Paradigms, Patterns of Learning and Development: an Introductory Roadmap", Journal of Evolutionary Economics 5, pp. 243-68 (1996).

Comín, Francisco (1995), La empresa pública en la España contemporánea: formas históricas de organización y gestión (1770-1995), Madrid, FEP, DT 9505. Publicado en Comín (1996), pp. 349-367.

Comín, F. and Pablo Martín Aceña, eds. (1996), La empresa en la Historia de España, Civitas, Madrid.

Comín and Martín Aceña. (1997), "Los rasgos históricos de las empresas en España: un panorama", Revista de Economía Aplicada, 12, pp.

De Miguel, Amando \& Linz, Juan J. (1964), "Características estructurales de las Empresas españolas: tecnificación y burocracia", Racionalización, 17, 1, pp.1-11; 2, 97-104; 3, 193-208 \& 4, 289296.

Donges, J.B., "From Autarchic Towards a Cautiously Out-Looking Economy", Weltwirtschaftliches 107 (1971).

Dunning, J. Multinational enterprise and the global economy (Wesley,1993)

Estapé-Triay, S. The dynamics of the firm in a changing environment. A case study of Ford and the Spanish motor industry in historical perspective, 1900-1990, Ph D thesis (Florence, 1997a)

Estapé-Triay, "Transforming Fordist Firms", 6th Congress of the Asociación de Historia Económica, 3r session, pp. 41-56 (1997b).

Estivill, J. \& Tomás, Josep R., "Apuntes para una historia de la organización del trabajo en España, 1900-1936", Sociología del Trabajo, 1, pp.17-43 (1979).

Farré, Antonio, "La regulación de la industria de automoción en España y sus relaciones con la industria del sector", Economia Industrial 252, pp. 27-43 (1986).

Fauri, Francesca, "The Role of Fiat in the Development of the Italian Car Industry in 1950's", Business History Review 70, pp. 167-207 (1996)

Glimstedt, Henrik, "Non-Fordist Routes to Modernization Production, Innovation and Political Construction of Markets in the Swedish Automobile Industry Before 1960", Business and Economic History 24, pp. 243-53 (1995)

Gómez Mendoza, A. El “Gibraltar económico." Franco y RioTinto, 1936-1954, (Madrid, 1994)

Guillén, Mauro F. (1994) Models of Management. Work, authority and organization in a comparative perspective, University of Chicago Press, Chicago.

Guillèn (1995) dt FEP 9502, Guía bibliográfica sobre organización de la empresa española hasta 1975, Madrid, FEP.

Herrero, José Luis (1990), "El papel del Estado en la introducción de la OCT en la España de los años cuarenta y cincuenta", Sociología del Trabajo, 9, pp. 141-166.

Jenkins, R.O., Dependent industrialization. The Automotive Industry in Chile, Argentina and Mexico (new York, Praeger, 1977)

Knoblaugh, Edward, "The motor Vehicle Vacuum in Spain", Automotive industries (July 15, 1949)

Kronish, Kenneth y R. Mericle, The Political Economy of Latin American Motor Vehicle Industry, (Cambridge, Mass., The MIT Press, 1984) 
Linz, J. y De Miguel, A. (1963-1964): "Fundadores, herederos y directores en las empresas españolas", Revista de Investigaciones Sociológicas, 81, pp. 5-38; 82, pp. 184-216 \& 85, pp. 5-28.

Little, Douglass, Malevolent Neutrality. The United States, Great Britain and the Origins of the Spanish Civil War, (Ithaca and London: Cornell University Press, 1985)

Martín Aceña, Pablo y Francisco Comín (1991), INI. 50 años de industrialización en España, EspasaCalpe, Madrid.

Molinas and Prados de la Escosura, "Was Spain different? Spanish historical backwardness revisited" Explorations in economic history 36, 4 (1989)

Muñoz, Juan (1969), El poder de la banca en España, Madrid.

Roldan, Santiago, Juan Muñoz \& Angel Serrano (1978), La internacionalización del capital en España, Madrid, Edicusa

Ortúnez, Pedro Pablo (1997), "Propiedad y control en las empresas ferroviarias españolas: el casode M.Z.A., 1913-1941", 6th Congress of the Asociación de Historia Económica, 3rd session, pp. 173-186.

San Román, Elena, $/ \mathbb{E l}$ nacimiento de SEAT: autarquía e intervención del INIØ, Revista de Historia Industrial, 7 (1995).

Schwartz, Pedro \& Manuel-Jesús González (1978), Una historia del Instituto Nacional de Industria (1941-1976), Madrid, Tecnos.

Shapiro, Helen "Determinants of Firm Entry into the Brazilian Automobile Manufacturing Industry, 1956-1968", Business History Review 65, pp. 876-947 (1991)

Shapiro, H. Engines of Growth: the State and Transnational Auto Companies in Brazil, (Cambridge: Cambridge University press, 1994)

Tignor, Robert, "In the Grips of Politics: The Ford Motor Company of Egypt, 1945-1960", Middle East Journal, 44,3, pp. 383-98 (1990).

Vegara, José $\mathrm{M}^{\mathrm{a}}$ (1971), La organización científica del trabajo. ¿Ciencia o ideología?, Fontanella, Barcelona, 1971

Wilkins, Mira and Frank Hill, American Enterprise Abroad: Ford on Six Continents, (Michigan, Wayne State University Press, 1964) 